\title{
Bt cotton and the predator Podisus nigrispinus (Dallas) (Heteroptera: Pentatomidae) in the management of Spodoptera frugiperda (J.E. Smith) (Lepidoptera: Noctuidae) resistance to lambda-cyhalothrin
}

\author{
J. B. Malaquias - C. Omoto $\cdot$ F. S. Ramalho • \\ W. A. C. Wesley $\cdot$ R. F. Silveira
}

Received: 20 December 2013/ Accepted: 26 March 2014/Published online: 26 April 2014

(C) Springer-Verlag Berlin Heidelberg 2014

\begin{abstract}
This study sought to provide relevant information for developing effective programs to manage Spodoptera frugiperda (J.E. Smith) (Lepidoptera: Noctuidae) resistance to insecticides by quantifying and describing the interactions between cotton $\mathrm{Bt}$ and Podisus nigrispinus (Dallas) (Heteroptera; Pentatomidae) in the management of lambda-cyhalothrin resistance in S. frugiperda fed Bt cotton leaves expressing Cry1Ac (Bollgard, Monsanto, St Louis, MO, USA). These effects were assayed by studying functional responses. Third instar S. frugiperda larvae were used for the following treatments: strains resistant (1) or susceptible (2) to lambda-cyhalothrin fed Bollgard cotton leaves and strains resistant (3) or susceptible (4) to lambdacyhalothrin fed non-Bt cotton leaves. The predatory behavior of $P$. nigrispinus females was best represented by a sigmoid curve. The type of $P$. nigrisinus functional response was not affected by the cotton cultivar or $S$. frugiperda strain used in the trials. P. nigrispinus females invested a greater amount of handling time $\left(T_{\mathrm{h}}\right)$ in $S$. frugiperda larvae that were suseptible to insecticides and fed non-Bt cotton $\left(T_{\mathrm{h}}=1.72 \mathrm{~h}\right)$ compared to those from the insecticide-resistant strain fed with Bt cotton $\left(T_{\mathrm{h}}=1.23 \mathrm{~h}\right)$ or even compared to those that were lambda-cyhalothrin resistant and fed $\mathrm{Bt}\left(T_{\mathrm{h}}=1.17 \mathrm{~h}\right)$ or non-Bt cotton
\end{abstract}

Communicated by N. Desneux.

J. B. Malaquias · F. S. Ramalho ( $\square)$

Biological Control Unit, CNPA, Embrapa Cotton (Unidade de

Controle Biológico, Embrapa Algodão), Osvaldo Cruz,

1143 - Centenário, Campina Grande, PB 58428-095, Brazil

e-mail: ramalhohvv@globo.com

C. Omoto · W. A. C. Wesley · R. F. Silveira

Department of Entomology and Acarology, Escola Superior de

Agricultura "Luiz de Queiroz", Piracicaba, SP, Brazil
$\left(T_{\mathrm{h}}=1.17 \mathrm{~h}\right)$. The results in the present study can be applied in the development of management programs targeting $S$. frugiperda resistance to pyrethroid lambda-cyhalothrin. The integration of Bt cotton concurrent with biological control by the Asopinae $P$. nigrispinus is important for successfully managing $S$. frugiperda resistance to lambda-cyhalothrin.

Keywords Biological control - Transgenic cotton · Resistance management · Lambda-cyhalothrin · Fall armyworm

Genetically modified crops offer new options for increasing the availability of food and sources of raw materials used by the textile industry in developing countries. Bt cotton was first employed in Brazil in 2005 with the approval of Bollgard cotton (Barros 2012). The transgenic Bt cotton cultivar, which harbors and expresses the Cry1Ac gene from the bacterium Bacillus thuringiensis Berliner, is toxic to the lepidopterans Alabama argillacea (Hübner) (Lepidoptera: Noctuidae), Heliothis virescens (Fabricius) (Lepidoptera: Noctuidae) and Pectinophora gossypiella (Saunders) (Lepidoptera: Gelechiidae), which are members of a group of defoliating and fruit larvae affecting Brazilian cotton production (Huesing and English 2004). Other genetically modified cultivars that confer resistance to insects have also been employed commercially in Brazil, including Bollgard II (Monsanto), which expresses Cry1 Ac and Cry2Ab2 (Colli 2011), WideStrike (Dow AgroSciences), which expresses pyramided Cry1F and Cry1Ac (Adamczyk et al. 2008), and TwinLink (Bayer), which contains the cry $1 \mathrm{Ab}$ and cry2Ae genes (Fok 2011). Recently, the Brazilian National Technical Commission on Biosafety approved the use of the Glytol $\times$ Twinlink 
(Bayer) (Wilkinson and Ford 2007) and MON $15985 \times$ MON 88913 (Randhawa and Chhabra 2013) cultivars for both controlling defoliating lepidopteran larvae and improving weed management. Because transgenic cotton should reduce insecticide application, it can also be used for managing insect resistance to conventional insecticides (Wu et al. 2005).

Spodoptera frugiperda (J.E. Smith) (Lepidoptera: Noctuidae) is a polyphagous migratory pest, which is endemic to the Western Hemisphere and can attack more than 80 plant species, including maize (Zea mays Linné), cotton (Gossypium hirsutum Linné), sorghum [Sorghum bicolor (Linné) Moench], rice (Oryza sativa Linné), millet [Pennisetum americanum (Linné) Bulrush], peanut (Arachis hypogaea Linné), alfalfa (Medicago sativa Linné), and other cultivated and wild plant species (Knipling 1980; Pashley 1986). It is typically controlled using insecticides based on the characteristics of its attacks (Diez-Rodriguez and Omoto 2001). There is a substantial gene flow in the animal populations collected from the cotton crop in Midwest Brazil, and a low variability is observed between populations collected on this crop. A correlation between the population structure and the cotton crop has not been detected (Martinelli et al. 2007). Nonetheless, different $S$. frugiperda populations have suffered constant selection pressures from insecticides used in various agricultural systems (Yu 1992; Leibee and Capinera 1995), which may have contributed to the establishment of populations resistant to several classes of insecticides in Brazil, such as pyrethroids (Diez-Rodriguez and Omoto 2001). The inheritance of resistance to the pyrethroid lambda-cyhalothrin by $S$. frugiperda is autosomal recessive (DiezRodriguez and Omoto 2001). The evolution of resistance tends to be delayed when inheritance is recessive (Roush and Mckenzie 1987). However, as resistance reaches a high frequency, the restoration of susceptibility in the absence of selective pressure can be slower because the resistant individuals that survive the application of an insecticide would all be homozygous (Roush and Mckenzie 1987).

The presence of effective natural enemies of pests in agroecosystems is one of the bio-ecological factors that should be considered for managing insecticide resistance. Transgenic cotton can positively affect generalist predator insects because indiscriminate pesticide applications can be reduced, thus increasing the population density of these natural enemies (Hagerty et al. 2005; Romeis et al. 2008; $\mathrm{Lu}$ et al. 2012). Defoliating lepidopteran larvae are an important group of pests that reside in cotton crops, and outbreaks of these pests are commonly associated with the occurrence of Pentatomidae predators (Pereira et al. 2010). These predators feed on a variety of prey species, which greatly contributes to the control of different insect pests (Ramalho 1994). The generalist predator Podisus nigrispinus (Dallas) (Heteroptera: Pentatomidae) could be potentially employed for biologically controlling several Lepidoptera species that thrive in Brazilian cotton crops, including the fall armyworm, S. frugiperda (Zanuncio et al. 2008). The predatory ability of $P$. nigrispinus is an important attribute that should be considered in management programs targeting defoliating lepidopteran larvae (Pereira et al. 2008).

Functional responses are used to assess the potential of natural enemies to control insect pests in various situations (Faria et al. 2004; Madadi et al. 2011). Predator-prey dynamics are directly influenced by the relationship between the available prey density and the number of prey attacked, which is a determining factor in the performance of predators in biological control systems (Holling 1959). An increase in prey availability can lead to increased predator consumption because the opportunities for encounter and attack will increase over time until satiation occurs (O'Neil 1990). The functional response of $P$. nigrispinus to $S$. frugiperda depends on the defensive capability of this prey species as well as its density (Zanuncio et al. 2008). Little is known about the functional responses of the neotropical predator $P$. nigrispinus to prey that develop on transgenic host plants and to prey larval strains that are resistant to this control tactic. Information describing the predatory or parasitic behavior of natural enemies for different pest genotypes (resistant or susceptible) is important for designing strategies to manage pest resistance to insecticides (Liu et al. 2012). This study sought to provide relevant information for developing effective programs to manage $S$. frugiperda resistance to insecticides by quantifying and describing the interactions between Bt cotton and P. nigrispinus in the management of lambda-cyhalothrin resistance in $S$. frugiperda fed Bt cotton leaves expressing Cry1Ac (Bollgard, Monsanto. St Louis, MO, USA). These effects were assayed by studying functional responses.

\section{Materials and methods}

Insects and cotton cultivars

The effects of Bt and non-Bt cotton ( $G$. hirsutum) cultivars together with $S$. frugiperda strains susceptible or resistant to the pyrethroid lambda-cyhalothrin on the functional responses of $P$. nigrispinus were quantified. The $S$. frugiperda populations used in this study were derived from a breeding stock maintained in the Laboratory of Insect Resistance to Control Tactics (Laboratório de Resistência de Insetos a Táticas de Controle-LRITC) at the Luiz de Queiroz School of Agriculture (Escola Superior de Agricultura "Luiz de Queiroz"—ESALQ), University of São 
Paulo (Universidade de São Paulo-USP), Piracicaba, São Paulo (SP), Brazil. The larvae were maintained in glass tubes $(2.5 \mathrm{~cm}$ in diameter by $8 \mathrm{~cm}$ in height) containing an artificial diet based on bean, wheat germ and beer yeast. The $S$. frugiperda-resistant strain was obtained through selection pressure applied at the LRITC. Newly emerged $P$. nigrispinus female adults were obtained from breeding colonies maintained at the Biological Control Unit of Embrapa Algodão, Campina Grande, Paraíba, Brazil. These insects were maintained at $26 \pm 1{ }^{\circ} \mathrm{C}$ under $70 \pm 10 \% \mathrm{RH}$ and a 12-h photophase. The temperature and photoperiod conditions were based on the recommendations of Medeiros et al. (2004) and Malaquias et al. (2009, 2010), respectively.

One genetically modified Bollgard cultivar (DP 404 $\mathrm{BG})$, which harbors a synthetic version of a gene from $B$. thuringinensis that encodes the Cry1Ac endotoxin, and another cultivar that lacked this endotoxin (cultivar DP4049) were used. The cultivars were supplied by Monsanto through an agreement between the company and the LRITC. The cultivars were planted in a greenhouse without controlled climatic conditions in plastic buckets (10-1 capacity). An organic substrate mixed with topsoil at a 1:1 ratio was used. The material was free of insecticide and/or acaricide. The leaves were collected from the top third of the plants in the vegetative phase, and plants that had flowered were discarded.

Two types of prey, corresponding to third-instar $S$. frugiperda larvae that were either resistant (I) or susceptible (II) to lambda-cyhalothrin, were used. These larvae were fed during their first and second instars on the aforementioned cotton cultivars (Bt and non-Bt cotton). The larvae utilized in the experiments were all active. The following experimental treatments were performed: S. frugiperda larvae that were resistant (1) or susceptible (2) to the pyrethroid were fed Bollgard (DP 404 BG) cotton leaves, and S. frugiperda larvae that were resistant (3) or susceptible (4) to lambda-cyhalothrin were fed non-Bt cotton leaves (cultivar DP4049). During the first and second instars, the $S$. frugiperda larvae received their food in transparent plastic vials (200-g capacity).

\section{Insect bioassays}

Newly emerged P. nigrispinus female adults were fasted for $24 \mathrm{~h}$ and were then individually transferred to PVC arenas $(30 \mathrm{~cm}$ high, $27 \mathrm{~cm}$ diameter) covered with an organza-type fabric. A leaf collected from the upper third portion of a cotton plant (approximately 2 months old) was placed in the center of each arena in a glass container. The arenas were maintained at $26 \pm 1{ }^{\circ} \mathrm{C}, 70 \pm 10 \% \mathrm{RH}$ and a 12-h photophase.
At 24-h intervals, each $P$. nigrispinus female was fed third-instar $S$. frugiperda larvae that were either resistant or susceptible to lambda-cyhalothrin and had been fed leaves from $\mathrm{Bt}$ or non-Bt cotton plants during the first to third instars at densities of 1, 2, 4, 8 and 16 larvae per leaf in each arena. Arenas with the same larvae densities were used to assess the larvae mortality in the absence of the predator to control for mortality due to cannibalism and the transgenic plant. To determine the predatory capacity of $P$. nigrispinus females as a function of the treatments, larvae exhibiting tegument lesions, a lack of mobility or whose body contents had been partially or completely removed by the predator were considered predated.

We employed a factorial experiment arranged in randomized blocks, which included the two cotton cultivars and two prey types (lambda-cyhalothrin susceptible and resistant), and five replicates were performed for each density. The same female was repeatedly provided the same number of larvae at 24-h intervals $(1,2,4,8$ or 16 larvae).

\section{Data analysis}

To determine the type of functional response that was observed, predation data from two trials were subjected to multinomial logistic regression analysis by using PROC GENMOD (SAS Institute 2006). Holling's (1959) equation was used to estimate the following parameters: the attack rate (a) when a type II response was observed (Eq. 1), the constant (b) when a type III response was detected (equation 2) and the handling time $\left(T_{h}\right)$ for both cases (types II and III). For the type II model, the following equation was used:

$N_{\mathrm{e}}=a N T /\left(1+a N T_{\mathrm{h}}\right)$

where $N_{\mathrm{e}}$ is the number of predated larvae; $N$ is the number of larvae offered; $a$ is the attack rate; $T$ is the total time available for the predator to eat the prey; $T_{\mathrm{h}}$ is the handling time. In some cases, the attack rate increased linearly ( $a=b N$, where $b$ is a constant), which resulted in a type III model of the functional response. Thus, the resulting model was a reduced type III equation (Juliano 1993)

$N_{e}=b N^{2} T /\left(1+b N^{2} T_{\mathrm{h}}\right)$.

The parameters handling time $\left(T_{\mathrm{h}}\right)$, attack rate $(a)$ and constant (b) were estimated via nonlinear regression (least squares method) using PROC NLIN (SAS Institute 2006). The coefficient of determination $\left(\mathrm{R}^{2}\right)$ of nonlinear models cannot be calculated as in linear models, $R^{2}=1-(\mathrm{SQR} /$ SQT), because most nonlinear models do not have an identifiable intercept. In this case, SAS uses the uncorrelated sum of squares instead of the total sum of squares (Freund and Littell 1986). The $R^{2}$ values of these models 


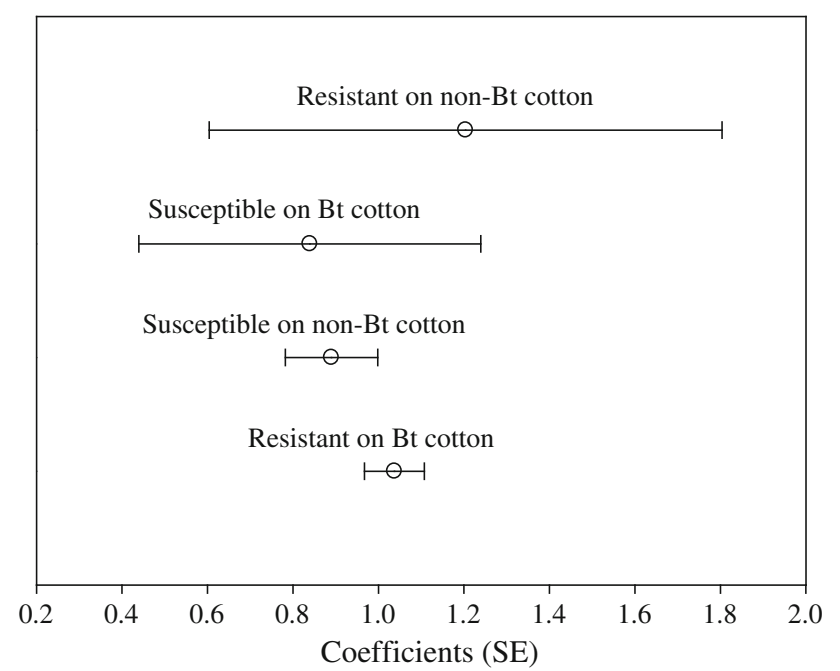

Fig. 1 Results of polynomial logistic regression analyses indicate the estimates and standard errors of linear coefficients for the proportion of prey killed from two strains of Spodoptera frugiperda by Podisus nigrispinus females relative to the initial prey numbers on Bt and nonBt cotton

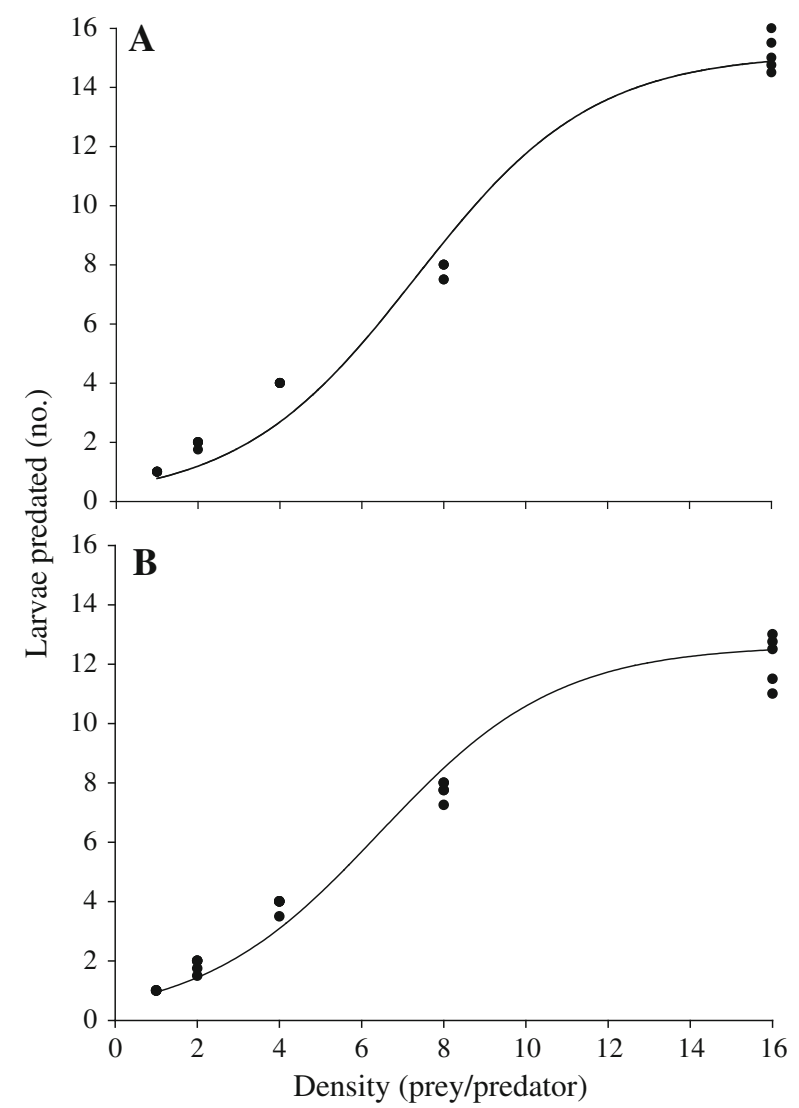

Fig. 2 Functional response of Podisus nigrispinus females to different densities of Spodoptera frugiperda larvae that were either susceptible to lambda-cyhalothrin on Bt cotton (a) and non-Bt cotton were calculated as $R^{2}=1-\left(S_{\mathrm{y}}^{2} / S_{\mathrm{td}}^{2}\right)$, where $S_{\mathrm{y}}^{2}$ is the variance of the model residuals and $S_{\mathrm{td}}^{2}$ is the variance of the observed means for consumption rates.

\section{Results}

In the absence of predators, independent of the tested density, the survival of third instar larvae of $S$. frugiperda was greater than $98 \%$. Therefore, it was not necessary to perform a correction for mortality due to cannibalism or the $\mathrm{Bt}$ plants. The sign of the linear coefficient from the polynomial logistic regression analysis was used to distinguish the shape of the functional response curve, with negative and positive values indicating type II and III responses, respectively (Juliano 1993). The results demonstrated that the predatory behavior of $P$. nigrispinus was best represented by the type III functional responses because, regardless of the treatment, the value of the linear coefficient was positive (Fig. 1). Thus, predatory behavior of $P$.

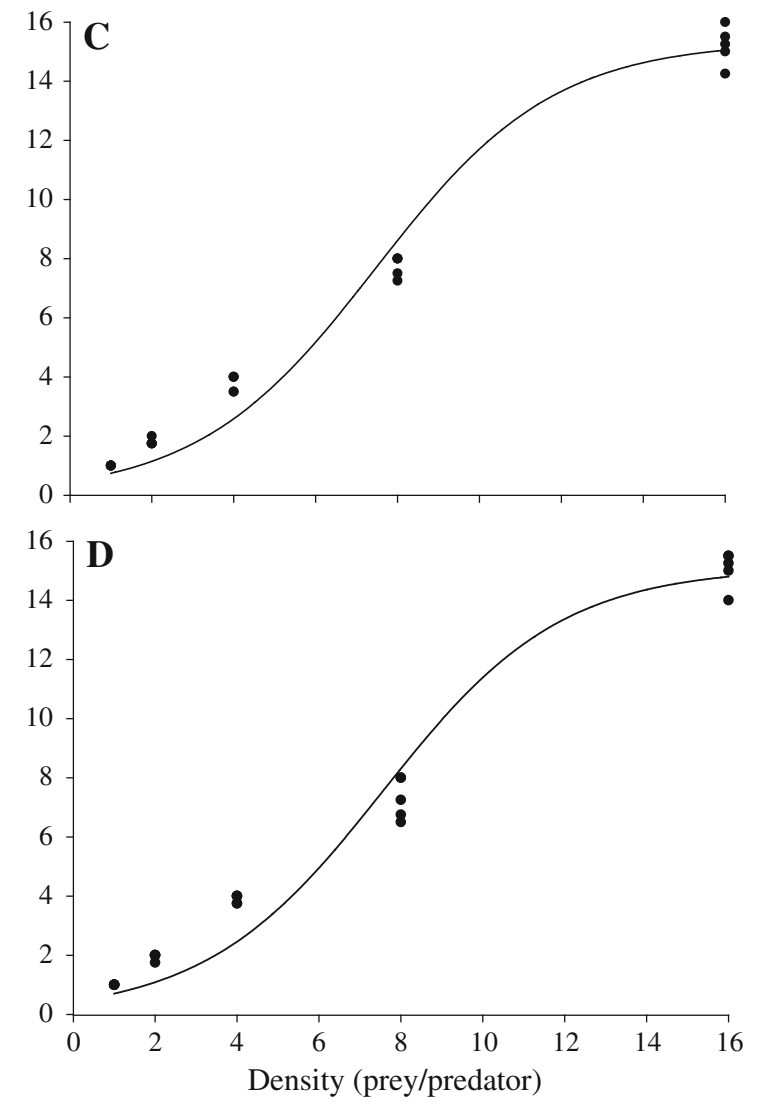

(b) or resistant to lambda-cyhalothrin on Bt cotton (c) and on non-Bt cotton (d). Data observed (points) and predicted (lines) for model of type III functional response 
Table 1 The mean constant " $b$ " and handling time $\left(T_{\mathrm{h}}\right)$ values (confidence interval) estimated by the disc equation, indicating a type III functional response of Podisus nigrispinus females to larvae of two Spodoptera frugiperda strains on Bt and non-Bt cotton

\begin{tabular}{|c|c|c|c|c|}
\hline Strain/cultivar & $b^{2}(95 \% \mathrm{CI})$ & $T_{\mathrm{h}}(\mathrm{h})(95 \% \mathrm{CI})$ & $R^{2}$ & $P>\mathrm{F}$ \\
\hline \multicolumn{5}{|c|}{ S. frugiperda susceptible to lambda-cyhalothrin } \\
\hline Bt cotton & $0.25(0.20-0.30) \mathrm{a}$ & $1.23(1.11-1.36) b$ & 0.97 & 0.0001 \\
\hline Non-Bt cotton & $0.32(0.26-0.38) \mathrm{a}$ & $1.72(1.59-1.85) \mathrm{a}$ & 0.96 & 0.0001 \\
\hline \multicolumn{5}{|c|}{ S. frugiperda resistant to lambda-cyhalothrin } \\
\hline Bt cotton & $0.23(0.19-0.27)$ a & $1.17(1.05-1.29) \mathrm{b}$ & 0.98 & 0.0001 \\
\hline Non-Bt cotton & $0.21(0.17-0.26) \mathrm{a}$ & $1.17(1.01-1.33) \mathrm{b}$ & 0.96 & 0.0001 \\
\hline
\end{tabular}

Values followed by the same letter (within a column) are not significantly different at the $5 \%$ level when the $95 \%$ confidence intervals of the estimates overlap

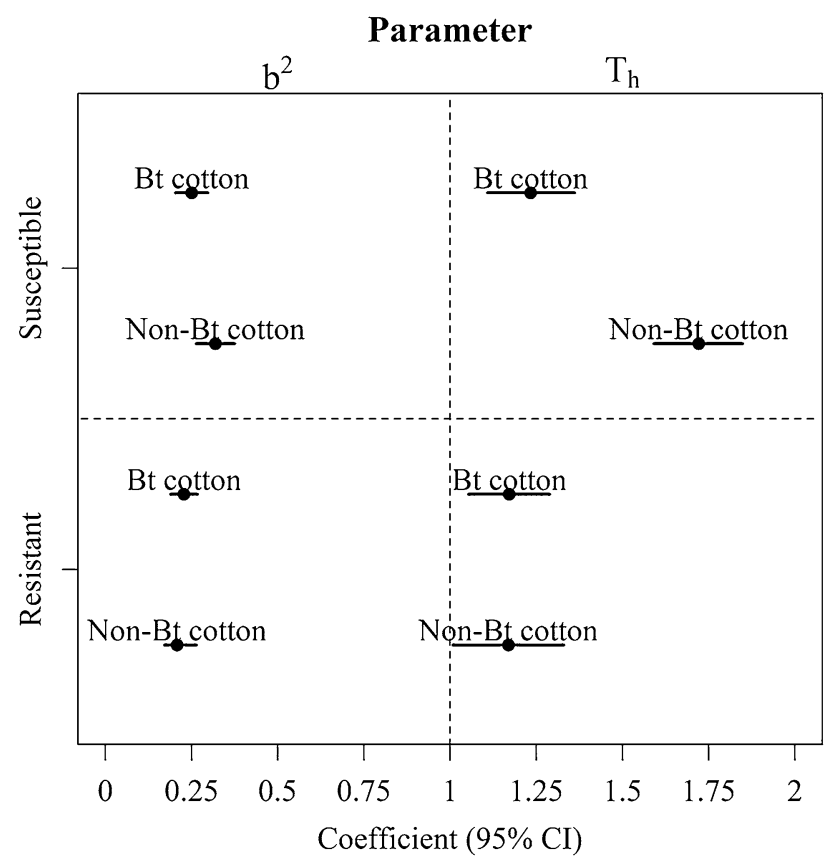

Fig. 3 The mean constant " $b$ " and handling time $\left(T_{\mathrm{h}}\right)$ values (confidence interval) estimated by the disc equation, indicating a type III functional response of Podisus nigrispinus females to larvae of Spodoptera frugiperda resistant on $\mathrm{Bt}\left(R^{2}=0.98\right)$ and non-Bt cotton $\left(R^{2}=0.96\right)$ and susceptible on $\mathrm{Bt}\left(R^{2}=0.97\right)$ and non-Bt cotton $\left(R^{2}=0.96\right)$. Values followed by the same letter are not significantly different at the $5 \%$ level when the $95 \%$ confidence intervals of the estimates overlap

nigrispinus irrespective of cotton cultivar and S. frugiperda strain was best represented by a sigmoid curve (Fig. 2).

The values of the constant " $b$ " obtained from the Holling's disc equation applied to the susceptible strain of $S$. frugiperda on Bt and non-Bt cotton were 0.25 and 0.32 , respectively, whereas values of 0.23 and 0.21 were obtained for the lambda-cyhalothrin resistant on $\mathrm{Bt}$ and non-Bt cotton, respectively. Thus, the attack rate of female $P$. nigrispinus preying on $S$. frugiperda larvae increased linearly (a-bN) irrespective of cotton cultivar and S. frugiperda strain. Furthermore, there was no significant difference in this variable " $b$ " among the studied conditions because there was an overlap in the confidence intervals (95\% CI) (Fig. 1).

The confidence intervals did not overlap between the handling time $\left(T_{\mathrm{h}}\right)$ observed in female P. nigrispinus offered $S$. frugiperda larvae susceptible to lambda-cyhalothrin and previously fed non-Bt cotton compared to the other treatments. Therefore, female $P$. nigrispinus invested more handling time $\left(T_{\mathrm{h}}\right)$ in $S$. frugiperda larvae that were susceptible to lambdacyhalothrin and fed non-Bt cotton $\left(T_{\mathrm{h}}=0.1 .72 \mathrm{~h}\right)$ compared to those from the lambda-cyhalothrin-resistant strain fed with Bt cotton $\left(T_{\mathrm{h}}=1.23 \mathrm{~h}\right)$ or even compared to those that were lambda-cyhalothrin resistant and fed $\mathrm{Bt}\left(T_{\mathrm{h}}=1.17 \mathrm{~h}\right)$ or nonBt cotton $\left(T_{\mathrm{h}}=1.17 \mathrm{~h}\right)$ (Table 1 and Fig. 3).

\section{Discussion}

The effectiveness of a predator is partly related to the type of its functional response in the field, and information obtained from laboratory experiments may be used to infer the basic mechanism of the predator-prey interactions under field conditions (Houck and Strauss 1985).

The type of functional response can be determined based on the sign of the linear coefficient, which is negative for type II and positive for type III (Juliano 1993). The findings of our study revealed that the predatory behavior of $P$. nigrispinus was best represented as a type III functional response, irrespective of cotton cultivar and S. frugiperda strain (Fig. 1).

Prey density dependence related to the predation of $A$. argillacea has been recorded in $P$. nigrispinus by Pereira et al. (2010). The functional response of predators may change from one type to another under different environmental conditions (Mohaghegh et al. 2001). According to Hassell (1978), the type of functional response of a given predator can change depending on the prey type. This change in response may be due to changes in the predator foraging behavior when exposed to a particular food source. Predators exhibit three types of functional responses (Holling 1959), and only type III yields a density- 
dependent mortality (Murdoch and Oaten 1975). The density-dependent mortality factors could regulate the population (Nicholson 1933) and stable equilibrium densities, and population oscillation damping would most likely occur with a type III rather than a type II functional response.

Researchers have similarly postulated that a predator with a type III functional response could regulate prey density more effectively than a predator with a type II functional response (Murdoch 1969, Murdoch and Oaten 1975). One postulated mechanism for type III functional responses is the concentration of predator hunting efforts in high-density patches (Hertlein and Thorarinsson 1987).

Predator responses as a function of prey density that are represented by a sigmoidal curve (type III) are crucial for programs that employ biological control agents because the predator can regulate the prey population through this type of behavior, even when the prey are dense (Murdoch and Oaten 1975).

The acquisition of more prey by the predator $P$. nigrispinus, especially with highly dense prey, implies a higher attack rate, which represents the prey-searching efficiency of this predator. The attack rate was a function of prey density $(a=b N)$, irrespective of cotton cultivar and $S$. frugiperda; however, there was a longer handling time $\left(T_{\mathrm{h}}\right)$ observed in predator females offered susceptible larvae that had previously been fed on non-transgenic cotton (Table 1).

The handling time parameter estimated in this study differs from those estimated by Zanuncio et al. (2008) for $P$. nigrispinus preying on $S$. frugiperda larvae. This difference is most likely related to the type of arena, densities, temperature and prey strains employed in these studies. Larvae that are susceptible to insecticides and fed non-Bt cotton are thought to exhibit higher nutritional quality (Ramalho et al. 2011) relative to larvae from the other experimental conditions, e.g., S. frugiperda larvae resistant to lambda-cyhalothrin and fed Bt cotton. According to Vivan et al. (2003) and Laycock et al. (2006), P. nigrispinus females require a longer handling time $\left(T_{\mathrm{h}}\right)$ for higher nutritional quality prey, i.e., they invest more time in capturing, attacking and ingesting this prey. Although the Bollgard cultivar does not cause a high mortality rate in $S$. frugiperda, this cultivar affects qualitative nutritional parameters, such as the production of feces and the rates of food metabolism and assimilation (Ramalho et al. 2011).

The results in the present study can be applied in the development of management programs targeting $S$. frugiperda resistance to pyrethroid lambda-cyhalothrin. Therefore, the integration of Bt cotton concurrent with biological control by the Asopinae P. nigrispinus is important for successfully managing $S$. frugiperda resistance to lambda-cyhalothrin. However, other factors should be considered in future studies because the functional response of an insect predator at different prey densities, in addition to being mediated by the interaction between these two trophic levels, may also be affected by morphological and biochemical traits of host plants, especially with zoophytophagous insects (De Clercq et al. 2000).

In conclusion, the results of our study revealed that (1) Bt cotton expressing Cry1 Ac (Bollgard) and the resistance of $S$. frugiperda larvae to lambda-cyhalothrin does not alter the type of functional response observed in P. nigrispinus, as indicated by the sign of the linear coefficient (positive for type III) (Juliano 1993), (2) the predatory behavior of $P$. nigrispinus is best represented by a type III functional response, irrespective of cotton cultivar and $S$. frugiperda strain (Fig. 3), and (3) female P. nigrispinus exhibited a higher handling time $\left(T_{\mathrm{h}}\right)$ for $S$. frugiperda larvae susceptible to lambda-cyhalothrin and fed non-Bt cotton.

Acknowledgments The authors would like to thank the Conselho Nacional de Desenvolvimento Científico e Tecnológico (CNPq) for the scholarships granted to the first author and also thank Embrapa Cotton for their technical support. Additional funds were received from the Brazilian agency Financiadora de Estudos e Projetos-FINEP.

\section{References}

Adamczyk Jr JJ, Greenberg S, Armstrong S Mullins WJ, Braxton LB, Lassiter RB, Siebert MW (2008) Evaluation of Bollgard II and WideStrike Technologies against beet and fall armyworms. In: Proceedings, Beltwide Cotton Conferences. National Cotton Council, Memphis, TN

Barros R (2012) Evaluation of Bt-cotton as strategy tool for the control of cotton plant-insects under field conditions. Cientifica 40:117-137

Colli W (2011) Organismos transgênicos no Brasil: regular ou desregular? Revista USP 89:148-173

De Clercq P, Mohaghegh J, Tirry L (2000) Effect of host plant on the functional response of the predator Podisus nigrispinus (Heteroptera: Pentatomidae). Biol Control 18:65-70

Diez-Rodriguez GI, Omoto C (2001) Herança da resistência de Spodoptera frugiperda (J.E. Smith) (Lepidoptera: Noctuidae) à lambda-cialotrina. Neotrop Entomol 30:311-316

Faria LDB, Godoy WAC, Trinca LA (2004) Dynamics of handling time and functional response by larvae of Chrysomya albiceps (Dipt., Calliphoridae) on different prey species. J Appl Entomol 128:432-436

Fok M (2011) Gone with transgenic cotton cropping in the USA. Biotechnol Agron Soc Environ 15:345-352

Freund RJ, Littell RC (1986) SAS system for regression. SAS Institute, Cary

Hagerty AM, Kilpatrick AL, Tumipseed SG, Sullivan ML (2005) Predaceous arthropods and lepidopteran pests on conventional, Bollgard, and Bollgard II cotton under untreated and disrupted conditions. Environ Entomol 34:105-114

Hassell MP (1978) The dynamics of arthropod predator-prey systems. Princeton University Press, Princeton

Hertlein MB, Thorarinsson K (1987) Variable patch times and the functional response of Leptopilina boulardi (Hymenoptera: Eucoilidae). Environ Entomol 16:593-598 
Holling CS (1959) Some characteristics of simple types of predation and parasitism. Can Entomol 91:385-398

Houck MA, Strauss RE (1985) A comparative study of functional responses: experimental design and statistical interpretation. Can Entomol 91:617-629

Huesing J, English L (2004) The impact of Bt crops on the developing world. AgBioForum 7:84-95

Institute Sas (2006) SAS/STAT user's guide. SAS Institute, Cary

Juliano SA (1993) Nonlinear curve fitting: predation and functional response curves. In: Scheiner SM, Gurevitch J (eds) Design and analysis of ecological experiments. Oxford University Press, New York, pp 159-182

Knipling EF (1980) Regional management of the fall armyworm: a realistic approach? Florida Entomol 63:468-480

Laycock A, Camm E, Van Laerhoven S, Gillespie D (2006) Cannibalism in a zoophytophagous omnivore is mediated by prey availability and plant substrate. J Insect Behav 19:219-229

Leibee GL, Capinera JL (1995) Pesticide resistance in Florida insects limits management options. Florida Entomol 78:386-399

Liu X, Chen M, Collins HL, Onstad D, Roush R, Zhang Q, Shelton AM (2012) Effect of insecticides and Plutella xylostella (Lepidoptera: Plutellidae) genotype on a predator and parasitoid and implications for the evolution of insecticide resistance. J Econ Entomol 105:354-362

Lu Y, Wu K, Jiang Y, Guo Y, Desneux N (2012) Widespread adoption of $\mathrm{Bt}$ cotton and insecticide decrease promotes biocontrol services. Nature 487:362-365

Madadi H, Parizi EM, Allahyari H, Enkegaard A (2011) Assessment of the biological control capability of Hippodamia variegata (Col.: Coccinellidae) using functional response experiments. J Pest Sci 84:447-455

Malaquias JB, Ramalho FS, Fernandes FS, Souza JVS, Azeredo TL (2009) Effects of photoperiod on the development and growth of Podisus nigrispinus, a predator of cotton leafworm. Phytoparasitica 37:241-248

Malaquias JB, Ramalho FS, Fernandes FS, Nascimento JL Jr, Correia ET, Zanuncio JC (2010) Effects of photoperiod on reproduction and longevity of Podisus nigrispinus (Heteroptera: Pentatomidae). Ann Entomol Soc Am 103:603-610

Martinelli S, Clark PL, Zucchi MI, Silva MC, Foster JE, Omoto C (2007) Genetic structure and molecular variabillity of Spodoptera frugiperda (Lepidoptera: Noctuidae) collected in maize and cotton fields in Brazil. Bull Entomol Res 97:225-231

Medeiros RS, Ramalho FS, Serrão JE, Zanuncio JC (2004) Estimative of Podisus nigrispinus (Dallas) (Heteroptera: Pentatomidae) development time with non linear models. Neotrop Entomol 33:141-148

Mohaghegh J, De Clercq P, Tirry L (2001) Functional response of the predators Podisus maculiventris (Say) and Podisus nigrispinus (Dallas) (Het., Pentatomidae) to the beet armyworm, Spodoptera exigua (Huëbner) (Lep., Noctuidae): effect of temperature. J Appl Entomol 125:131-134

Murdoch WW (1969) Switching in generalist predators: experiments on predator specificity and stability of prey populations. Ecol Monogr 39:335-354
Murdoch WW, Oaten A (1975) Predation and population stability. Adv Ecol Res 9:1-131

Nicholson AJ (1933) The balance of animal populations. J Anim Ecol 2:132-178

O'Neil RJ (1990) Functional response of arthropod predators and its role in the biological control of insect pests in agricultural systems. In Alan RL (ed.), New direction in biological control: alternatives for suppressing agricultural pests and diseases. West Lafayette: Purdue University, Indiana, pp 83-86

Pashley DP (1986) Host associated genetic differentiation in fall armyworm (Lepidoptera: Noctuidae): a sibling species complex? Ann Entomol Soc Am 79:898-904

Pereira AIA, Ramalho FS, Malaquias JB, Bandeira CM, Silva JES, Zanuncio JC (2008) Density of Alabama argillacea larvae affects food extraction by females of Podisus nigrispinus. Phytoparasitica 36:84-94

Pereira AIA, Ramalho FS, Rodrigues KCV, Malaquias JB, Souza JVS, Zanuncio JC (2010) Food extraction by the males of Podisus nigrispinus (Dallas) (Hemiptera: Pentatomidae) from cotton leafworm larvae. Braz Arch Biol Technol 53:1027-1035

Ramalho FS (1994) Cotton pest management. Part 4. A Brazilian perspective. Annu Rev Entomol 34:563-578

Ramalho FS, Azeredo TL, Nascimento ARB, Fernandes FS, Nascimento JR Jr, Malaquias JB, Domingues da Silva CA, Zanuncio JC (2011) Feeding of fall army worm, Spodoptera frugiperda, on Bt transgenic cotton and its isoline. Entomol Exp Appl 139:207-214

Randhawa GJ, Chhabra R (2013) Genetically modified cotton in India and detection strategies. Methods Mol Biol 958:17-28

Romeis J, van Driesche RG, Barrat BIP, Bigler F (2008) Insect resistant transgenic crops and biological control. In Romeis $\mathrm{J}$, Shelton AM, Kennedy GG (eds.). Integration of insect-resistant genetically modified crops within IPM programs. Springer, Dordrecht, pp 87-118

Roush RT, Mckenzie JA (1987) Ecological genetics of insecticide and acaricide resistance. Annu Rev Entomol 32:361-380

Vivan LM, Torres JB, Veigas AFSL (2003) Development and reproduction of a predatory stinkbug, Podisus nigrispinus in relation to two different prey types and environmental conditions. Biocontrol 48:155-158

Wilkinson MJ, Ford CS (2007) Estimating the potential for ecological harm from gene flow to crop wild relatives. Biosafety Rev 3:42-63

Wu K, Mu W, Liang G, Guo Y (2005) Regional reversion of insecticide resistance in Helicoverpa armigera (Lepidoptera: Noctuidae) is associated with the use of $\mathrm{Bt}$ cotton in northern China. Pest Manag Sci 61:497-498

Yu SJ (1992) Detection and biochemical characterization of insecticide resistance in fall armyworm (Lepidoptera: Noctuidae). J Econ Entomol 85:675-682

Zanuncio JC, Silva CAD, Rodrigues E, Pereira FF, Ramalho FS, Serrão JE (2008) Predation rate of Spodoptera frugiperda (Lepidoptera: Noctuidae) larvae with and without defense by Podisus nigrispinus (Heteroptera: Pentatomidae). Braz Arch Biol Technol 51:125-129 